\title{
Pathogenic Groups Identified Among Isolates of Rhynchosporium secalis
}

\author{
Mohammad Imad Eddin Arabi*, Eyad Al-Shehadah and Mohammad Jawhar \\ Department of Molecular Biology and Biotechnology, AECS, P.O. Box 6091, Damascus, Syria \\ (Received on April 5, 2010; Accepted on May 31, 2010)
}

\begin{abstract}
Scald, caused by Rhynchosporium secalis has been the major yield-reducing factor for barley production during the last decade. In this study, pathogenic groups of $R$. secalis were identified to obtain a global picture of the assembly of isolates involved in Syrian populations which is essential for the development of scald-resistant barley cultivars. To identify a number of pathogenic groups, 49 isolates collected over ten years from major barley growing areas in Syria were evaluated on five differential barley genotypes. Genotypes presented a continuous range of response from highly susceptible to moderately resistant, but none were immune to the disease. A cluster analysis placed isolates in six distinct differential pathogenic groups. Mean disease rating of $39.24 \%$ was the separation point between avirulent and virulent reactions. Isolate Rs46 exhibited distinct differential virulence patterns associated with high frequency across all genotypes. Hence, the data presented here provides crucial information for future selection of isolates to develop durable barley scald resistance.
\end{abstract}

Keywords : barley resistance, frequency of virulence, scald, pathogen population

Rhynchosporium secalis (Oudem.) J. J. Davis, the causal agent of scald, is an important pathogen of barley (Hordeum vulgare L.) found worldwide. This pathogen is considered economically important because it can cause marked reduction in yield and quality of the crop (Brown et al., 1996; Yahyaoui 2003; Meles et al., 2005).

Although fungicides can be effective in reducing scald severity (Stedman, 1980), the most effective and environmentally sound means of control is through the use of resistant cultivars. Development of stable forms of resistance to foliar diseases depends upon identification of resistances effective against the prevalent isolates in barley growing areas (Xi et al., 2000). Variations in barley resistance to scald were reported (Jørgensen and Smedegaard-Peterson, 1995; $\mathrm{Xi}$ et al., 2002; Zaffarano et al., 2006). The value of resistance to this disease depends mainly on its level and its

\footnotetext{
*Corresponding author.

Phone) 00963-11-2132580, FAX) 00963-11-6112289

E-mail)scientific@aec.org.sy
}

durability in relation to the life span of the genotypes.

However, before resources are committed to control scald disease, the identification of pathogenic groups of isolates expressing differential virulence on barley genotypes should be evaluated. Field assessment is time-consuming and several environmental interactions such as inoculum and moisture make it impossible to obtain error-free estimates (Mert and Karakaya, 2003).

To effectively breed scald resistance barley, it is essential to have information on the pathogenicity groups in $R$. secalis. Therefore, the aim of the present research was mainly to investigate, the pathogenic groups of $R$. secalis collected from different regions of Syria isolates under controlled conditions, which can be used in future breeding programs to facilitate the deployment of effective resistance to $R$. secalis in barley.

Fungal isolates and inoculum preparation. Over ten years, more than 115 isolates of $R$. secalis were obtained from barley leaves showing scald symptoms in different regions of Syria. Leaves were placed in paper envelopes and allowed to air-dry at room temperature for at least $48 \mathrm{~h}$. Dried leaves were soaked for $10 \mathrm{~s}$ in $70 \%$ ethanol, surface sterilized for $60 \mathrm{~s}$ in a 5\% sodium hypochlorite solution, and rinsed in distilled water for $10 \mathrm{~s}$ like wise for the preceding lines. The sterilized leaves were cut into small pieces $(5 \mathrm{~mm}$ in length) and transferred to Petri dishes containing potatodextrose agar (PDA, Difco, MI, USA). After incubation for $48 \mathrm{~h}$, at $15^{\circ} \mathrm{C}$ in the dark, fine glass needles were used to remove small tufts of mycelia that emerged around lesion borders. Mycelial tufts were transferred to Petri dishes containing lima bean agar (LBA). After incubation at $15^{\circ} \mathrm{C}$ for 1 to 2 weeks, colonies were spread across fresh LBA plates and incubated for an additional 2 to 3 weeks at $15^{\circ} \mathrm{C}$. Spores and mycelial fragments were collected by adding 1 $\mathrm{ml}$ of sterile distilled water and scraping gently across the mycelium with a sterile glass microscope slide. In preliminary studies, different barley genotypes had been inoculated with 115 fungal isolates, evaluating host reactions and lesion forms. Emphasis was placed on selecting isolates that induced differential reactions on specific genotypes, leading to selection of the 49 monosporic isolates used in this study (Table 1). A suspension of conidia from 12- day-old cultures 
Table 1. Mean disease rating of 49 isolates of Rhynchosporium secalis on 5 barley genotypes used as differentials

\begin{tabular}{|c|c|c|c|c|c|c|c|}
\hline \multirow{2}{*}{ Isolates (No.) } & \multirow{2}{*}{$\begin{array}{c}\text { Year of } \\
\text { collection }\end{array}$} & \multicolumn{6}{|c|}{ Mean rating } \\
\hline & & Tadmor & Igri & WI2291 & Golf & Arabi Abiad & Mean \\
\hline Rs1 & 1997 & 5.4 & 10.4 & 58.9 & 20.2 & 36.5 & $26.3 \mathrm{~h}$ \\
\hline Rs2 & 2004 & 40.7 & 49.8 & 77.1 & 43.7 & 79 & $58.6 \mathrm{ef}$ \\
\hline Rs3 & 2004 & 32.3 & 29.8 & 85.5 & 37.4 & 70.6 & $51.1 \mathrm{e}$ \\
\hline Rs4 & 2004 & 3.7 & 9.1 & 35.2 & 30.5 & 53.3 & $26.4 \mathrm{~h}$ \\
\hline Rs5 & 2004 & 43.6 & 59.6 & 89.2 & 79.7 & 87.6 & $71.9 \mathrm{~b}$ \\
\hline Rs6 & 2006 & 50.8 & 39.8 & 89.3 & 87 & 84.2 & $70.2 \mathrm{bc}$ \\
\hline Rs7 & 2003 & 1.9 & 14.2 & 80.8 & 17 & 13 & $25.4 \mathrm{~h}$ \\
\hline Rs8 & 2006 & 20.6 & 56.6 & 39.4 & 55.9 & 40.5 & $42.6 c$ \\
\hline Rs9 & 2003 & 2.5 & 5.7 & 31.5 & 52 & 57.2 & $29.8 \mathrm{gh}$ \\
\hline Rs10 & 2003 & 4.7 & 32.4 & 88.6 & 18.5 & 50.6 & $38.9 \mathrm{ef}$ \\
\hline Rs11 & 2003 & 0.7 & 7.2 & 37 & 27.6 & 34 & $21.3 \mathrm{i}$ \\
\hline Rs12 & 2001 & 1.3 & 4.8 & 20 & 33.6 & 26.6 & $17.3 \mathrm{ij}$ \\
\hline Rs13 & 2004 & 12.6 & 10 & 90.2 & 81.6 & 81.6 & $55.2 \mathrm{ef}$ \\
\hline Rs14 & 2001 & 15 & 53.5 & 40.3 & 54.1 & 44.5 & $41.4 \mathrm{fg}$ \\
\hline Rs15 & 2003 & 7.6 & 19.2 & 78.8 & 28 & 52.1 & 37.1ef \\
\hline Rs16 & 1997 & 8.5 & 12.3 & 58.4 & 27 & 62.6 & $33.8 \mathrm{~g}$ \\
\hline Rs17 & 2003 & 41 & 30 & 93.2 & 78.8 & 88.6 & $66.3 \mathrm{~cd}$ \\
\hline Rs18 & 2003 & 7.3 & 9.1 & 77.5 & 52.9 & 57.4 & $40.8 \mathrm{fg}$ \\
\hline Rs19 & 2003 & 43.8 & 49.6 & 63.5 & 72.3 & 72.5 & $60.3 \mathrm{bc}$ \\
\hline Rs20 & 2004 & 1.2 & 12.1 & 66.2 & 87 & 84.2 & $50.1 \mathrm{e}$ \\
\hline Rs21 & 2004 & 6.1 & 4.7 & 58.2 & 17 & 13 & $19.8 \mathrm{i}$ \\
\hline Rs22 & 2001 & 19.2 & 36.1 & 80.8 & 76.6 & 77.7 & $58.1 \mathrm{e}$ \\
\hline Rs23 & 2001 & 2 & 7.9 & 30.4 & 14.3 & 21.1 & $15.1 \mathrm{j}$ \\
\hline Rs24 & 2001 & 6.4 & 23.1 & 77.5 & 52.9 & 57.4 & $43.5 \mathrm{fg}$ \\
\hline Rs25 & 2001 & 15.6 & 29.1 & 60.7 & 79.7 & 86.1 & $54.2 \mathrm{gh}$ \\
\hline Rs26 & 2003 & 15 & 11.3 & 53.4 & 86.5 & 88.1 & $50.9 \mathrm{e}$ \\
\hline Rs 27 & 2003 & 7.2 & 8.7 & 53.8 & 17 & 13 & 19.9ij \\
\hline Rs28 & 2003 & 43.8 & 34.4 & 70.5 & 74.6 & 77.8 & $60.2 \mathrm{~d}$ \\
\hline Rs29 & 2003 & 2.8 & 16.5 & 52.4 & 10 & 12.3 & $18.8 \mathrm{ij}$ \\
\hline Rs30 & 2004 & 3.7 & 25.1 & 60 & 45.6 & 63 & $39.5 \mathrm{de}$ \\
\hline Rs31 & 2006 & 7.1 & 9.6 & 68.8 & 27.1 & 64.6 & $35.5 \mathrm{ef}$ \\
\hline Rs32 & 2006 & 7.2 & 7.6 & 70.4 & 28.3 & 56.6 & $34.1 \mathrm{fg}$ \\
\hline Rs33 & 2006 & 3.1 & 12.9 & 51.1 & 12.1 & 26.6 & $21.2 \mathrm{i}$ \\
\hline Rs34 & 2003 & 11.1 & 8.8 & 85 & 46.6 & 52 & $40.7 \mathrm{fg}$ \\
\hline Rs35 & 2003 & 5.7 & 7.8 & 77 & 39.3 & 16.5 & $29.3 \mathrm{~h}$ \\
\hline Rs36 & 2003 & 3.9 & 7.2 & 77.5 & 46 & 53.8 & $37.7 \mathrm{ef}$ \\
\hline Rs37 & 2006 & 48.6 & 29.3 & 93.3 & 88.5 & 89 & $69.7 \mathrm{bc}$ \\
\hline Rs38 & 2006 & 22.1 & 23.5 & 89.1 & 73.6 & 82.3 & $58.1 \mathrm{ef}$ \\
\hline Rs39 & 2006 & 1.1 & 8.6 & 24.8 & 66.3 & 69 & $33.9 \mathrm{fg}$ \\
\hline Rs40 & 2006 & 9.7 & 19.5 & 61.5 & 86.5 & 88 & $53.0 \mathrm{gh}$ \\
\hline Rs41 & 2006 & 0.3 & 11.9 & 48.9 & 17 & 22.6 & $20.1 \mathrm{i}$ \\
\hline Rs42 & 2006 & 2.4 & 46.5 & 48.2 & 43.6 & 26.8 & $33.5 \mathrm{de}$ \\
\hline Rs43 & 2006 & 4.2 & 7.3 & 76.3 & 24 & 27.8 & $27.9 \mathrm{~h}$ \\
\hline Rs44 & 2006 & 5 & 19.4 & 80.8 & 44.2 & 62.3 & $42.3 \mathrm{fg}$ \\
\hline Rs45 & 2006 & 5.1 & 13.6 & 64.8 & 74.3 & 48.7 & $41.3 \mathrm{fg}$ \\
\hline Rs46 & 2006 & 55.6 & 43.3 & 97 & 86.3 & 93.7 & $75.2 \mathrm{a}$ \\
\hline Rs47 & 2006 & 4.6 & 5.3 & 41.2 & 33.8 & 58.9 & $28.8 \mathrm{fg}$ \\
\hline Rs48 & 2006 & 3.3 & 5.9 & 40.9 & 50.5 & 40.2 & $28.1 \mathrm{fg}$ \\
\hline Rs49 & 2006 & 2 & 7 & 43.8 & 29.6 & 17.6 & $20.0 \mathrm{i}$ \\
\hline mean & & 13.65 & 20.55 & 64.05 & 48.5 & 54.75 & \\
\hline
\end{tabular}

Values followed by different letters are significantly different at $(\mathrm{P}<0.001)$ according to Newman-Keuls test. 
was adjusted to $0.5 \times 10^{6}$ spores $/ \mathrm{ml}$ using a hemacytometer. Tween 20 (polyoxyethylene-sorbitan monolaurate) was added as a surfactant $(100 \mu \mathrm{l}$ per liter $)$ to the conidial suspension to facilitate dispersion of the inoculum over the leaf surface.

Pathogenicity test. Pathogenicity of the 49 isolates was conducted "under growth room conditions" using two different barley genotypes from Syria (Tadmor and Arabi Abiad), Germany (Igri), UK (Golf) and Australia (WI2291). They were chosen for their differential reactions to scald (Arabi et al. 2008). Seeds were surface-sterilized with 5\% sodium hypochlorite solution for $5 \mathrm{~min}$, washed three times in sterile distilled water, then planted in plastic flats $(60 \times 40$ $\times 8 \mathrm{~cm}$ ) filled with sterilized peatmoss, and arranged in a randomized complete block design with three replicates. Each experimental unit consisted of two rows of 18 seedlings per genotype. A full replicate consisted of 5 genotypes inoculated with each of the 49 isolates. Flats were placed in a growth chamber at $22 \pm 1{ }^{\circ} \mathrm{C}$ (day) and $17 \pm 1{ }^{\circ} \mathrm{C}$ (night) with a day length of $12 \mathrm{~h}$ and a relative humidity of $80 \sim 90 \%$. Seedlings were irrigated with Knop's nutrient solution $\left(1 \mathrm{~g} \mathrm{NaNO}_{3} ; 0.25 \mathrm{~g} \mathrm{KNO}_{3} ; 0.25 \mathrm{~g} \mathrm{MgSO}_{4}\right.$ $7 \mathrm{H}_{2} \mathrm{O}$; $0.25 \mathrm{~g} \mathrm{KH}_{2} \mathrm{PO}_{4}$; and $10 \mathrm{mg} \mathrm{FeCl}_{3}$ per $1000 \mathrm{ml}$ of water). Plants were inoculated at growth stage 13 (Zadoks et al., 1974) by uniformly spraying each flat with $25 \mathrm{ml}$ of conidial suspension with a hand-held spray bottle. Disease severity was assessed on the lamina of the second leaf from the base of each plant 17 days after inoculation, using the rating scale described by Salamati and Tronsmo (1997). Briefly, a 0-to-5 scale was used, where $0=$ symptom free, 1 $=$ traces or small necrotic flecks, $2=$ some chlorosis or necrosis along margins, $3=$ necroses but less than $40 \%$ affected tissue, $4=$ necroses on 40 to $80 \%$ of the lamina, and $5=$ more than $80 \%$ and up to a fully wilted leaf.

Statistical analysis. The experiment was repeated twice. The mean of disease severity was first calculated for each isolate separately, and the mean values for each group and correlations were calculated using STAT-ITCF program and
Student-Newman-Keuls test (Anonymous, 1988). A separation point for resistant and susceptible classes was calculated by taking the average disease ratings of the two middle clusters and adding the standard error (SE) of the means (Eyal et al., 1985). The average disease rating of the two middle clusters was $38.6 \%$. A standard error of the mean was calculated by taking the square root of the error mean square and dividing it by the square root of replicates $(\mathrm{SE}=$ error $\mathrm{MS} / \mathrm{r}=1.92$ / $3=0.64$ ). The final separation point was $38.6+0.64=$ $39.24 \%$. Genotypes rated higher than $39.24 \%$ were consider-zed susceptible and those lower than $39.24 \%$ were considered resistant. The frequency of virulence for each isolate was calculated by dividing the number of genotypes with a susceptible reaction by the total number.

Analysis of variance showed that there were highly significant differences $(P<0.001)$ among genotypes, isolates and their interaction (Table 1). WI2291 was susceptible; Arabi Abiad and Golf were moderately susceptible. Whereas, the genotypes Tadmor and Igri, were moderately resistant despite the fact that Igri possesses the BRR4 resistance gene to $R$. secalis (Bouajila et al., 2006).

The results demonstrated that the isolates varied greatly in pathogenicity. However, isolate, Rs46 (with an average of $75.20 \%$ ) should be singled out as being extremely sever since unlike all other isolates, no single genotype could show any degree of tolerance against it.

Using cluster analysis, the isolates were split into six groups based on the infection response of each genotype (Table 2). Group 1 which contained 10 isolates (Rs1, 21, $27,29,33,41,11,49,23,12)$ had the lowest virulence level $(20 \%)$ associated with the lowest frequency of virulence $(14 \%)$, whereas, group 6 which contained seven isolates (Rs5, 19, 6, 37, 46, 17, 28) exhibited a high virulence level $(67.7 \%)$ and a low frequency of virulence $(19.40 \%)$, the remaining groups were moderately susceptible to moderately resistant towards $R$. secalis (Table 2).

This study conducted under controlled conditions and at a specific seedling development stage demonstrated that none of the tested genotypes were immune to infection. Our data demonstrated that $R$. secalis is comprised of six

Table 2. Cluster analysis of mean disease rating of 49 isolates of Rhynchosporium secalis on 5 barley genotypes

\begin{tabular}{|c|c|c|c|}
\hline Group & Isolates in group & Frequency of virulence $(\%)$ & Mean disease rating ${ }^{a}$ \\
\hline 1 & Rs1, 21, 27, 29, 33, 41, 11, 49, 23, 12 & $14.0 \%$ & $20.0 \mathrm{e}^{\mathrm{b}}$ \\
\hline 2 & Rs7, 43, 35 & $26.6 \%$ & $31.7 \mathrm{de}$ \\
\hline 3 & Rs $10,42,15,16,31,32,30,4,9,39,36,34,24,44,47,48,45$ & $47.0 \%$ & $35.6 \mathrm{~d}$ \\
\hline 4 & Rs $18,8,14$ & $70.0 \%$ & $41.6 \mathrm{c}$ \\
\hline 5 & Rs13, 22, 38, 20, 26, 40, 25, 2, 3 & $62.2 \%$ & $53.4 \mathrm{~b}$ \\
\hline 6 & Rs5, 19, 6, 37, 46, 17, 28 & $91.4 \%$ & $67.7 \mathrm{a}$ \\
\hline
\end{tabular}

${ }^{a}$ Values are the average of the disease rating of five barley genotypes replicated three times, calculated on the basis of $0-5$ scale, (see the text).

${ }^{b}$ Values followed by different letters are significantly different at $(P<0.001)$ according to the Newman-Keuls test. 
distinct pathogenicity levels based on the infection response of barley genotypes. These results are in close agreement with those obtained by Tekauz (1991); Bouajila et al. (2006). The genotypes used in our study were effective for characterizing $R$. secalis pathogenicity since all gave clear response (high to low) to the pathogen isolates studied (Table 1). In our experiment, the amount of inoculum was controlled, and consistently produced sufficient numbers of well-separated lesions for assessing infection responses on barley plants. Presence of highly susceptible genotypes to this pathogen might be an indication that breeders can not rely on natural selection pressure since it is not practiced in a sufficiently uniform manner.

Our data demonstrated that there was significant variation in pathogenicity of $R$. secalis among Syrian isolates. This can be attributed to the genotype interactions, and that several genes for virulence are operating in the pathosystem (Brown et al. 1996; Goodwin et al., 1994). The observed variation in the virulence of $R$. secalis in this study is in line with the results of Forgan et al. (2007).

The results show that isolate Rs46 has the highest mean disease rating $(75.20 \%)$ and a low frequency of virulence $(19.40 \%)$. Therefore this isolate may be considered as a useful virulent isolate in the future plant-breeding program. Whereas, Rs12 and Rs23 isolates would be of no use in screening breeder's material due to its lack of virulence.

Characterization of different pathogenicity groups of $R$. secalis can facilitate the molecular mapping of scald and the selection of resistant lines in the field (Jørgensen and Smedegaard-Peterson, 1995; Zaffarano et al., 2006). The classification of plants into resistant and susceptible categories is a primary consideration in the selection of resistant breeding lines and in studies on host-pathogen genetics. However, if virulent pathotypes already exist, their increase will depend on their initial frequency and relative fitness. In addition, the results indicate a need to monitor the virulence situation in $R$. secalis which will facilitate studies on the inheritance of resistance to this pathogen. Moreover, knowledge of the $R$. secalis virulence spectrum may help in designing proper resistance breeding strategies.

\section{Acknowledgments}

The authors thank the Director General of Atomic Energy Commission of Syria and the Head of Biotechnology Department for their support.

\section{References}

Anonymous, 1988. STAT-ITCF, Programme, MICROSTA, realized by ECOSOFT, $2^{\text {nd }}$ Ver. Institut Technique des Cereals et des Fourrages Paris, France.
Arabi, M. I. E., Jawhar M. and Al-Shehadah, E. 2008. Molecular and pathogenic variation identified among isolates of Rhynchosporium secalis from Syria. J. Plant Pathol. 90:179-184.

Bouajila, A., Haouas, S., Fakhfakh, M., Rezgui, S. and Yahyaoui, A. 2006. Pathotypic diversity of Rhynchosporium secalis (oudum) in Tunisia. Afri. J. Biotechnol. 5:570-759.

Brown, A. H. D., Garvin, D. F., Burdon, J. J., Abbott, D. C. and Read, B. J. 1996. The effect of combining scald resistance genes on disease levels, yield and quality traits in barley. Theor. Appl. Genet. 93:361-366.

Eyal, Z., Scharen, A. L., Huffman, M. D. and Prescott, J. M. 1985. Global insights into virulence frequencies of Mycosphaerella graminicola. Phytopathology 75:1456-1462.

Forgan, A. H., Knogge, W. and Anderson, P. A. 2007. Asexual Genetic Exchange in the Barley Pathogen Rhynchosporium secalis. Phytopathology 97:650-654.

Goodwin, S. B., Webster, R. K. and Allard, R. W. 1994. Evidence for mutation and migration as sources of genetic variation in populations of Rhynchosporium secalis. Phytopathology 84: 1047-1053.

Jørgensen, H. J. L. and Smedegaard, P. V. 1995. Pathogenic variation of Rhynchosporium secalis in Denmark and sources of resistance in barley. J. Phytopathol. 79:297-301.

Meles, K., Udupa, A., Abang, S. M. M., Abu-Blan, H., Baum, M., Ceccarelli, S. and Yahyaoui, A. H. 2005. Amplified fragment length polymorphism among Rhynchosporium secalis isolates collected from a single barley field in Syria. Ann. Appl. Biol. 146:389-394.

Mert, Z. and Karakaya, A. 2003. Determination of the suitable inoculum concentration for Rhynchosporium secalis seedling assays. J. Phytopathol. 151:699-701.

Salamati, S. and Tronsmo, M. 1997. Pathogenicity of Rhynchosporium secalis isolates from Norway on 30 cultivars of barley. Plant Pathol. 46:416-424.

Stedman, O. J. 1980. Observations on the production and dispersal of spores, and infection by Rbynchosporium secalis. Ann. Appl. Biol. 5:163-175.

Xi, K., Xue, A., Burnett, P. A., Helm, J. H. and Turkington, T. K. 2000. Quantitative resistance of barley cultivars to Rhynchosporium secalis. Can. J. Plant Pathol. 22:217-223.

Xi, K., Turkington, T. K., Helm, J. H. and Bos, C. 2002. Pathogenic variation of Rhynchosporium secalis in Alberta. Can. J. Plant Pathol. 24:176-183.

Tekauz, A. 1991. Pathogenic variation in Rhynchosporium secalis on barley in Canada. Can. J. Plant Pathol. 13:298-304.

Yahyaoui, A. H. 2003. Occurrence of barley leaf blight diseases in Central West Asia and North Africa. In: Proceedings of the Second International Workshop on Barley Leaf Blights, 7-11 April (2002) ICARDA, Aleppo, Syria. Yahyaoui AH, Brader L., Tekauz A., Wallwork H., Steffenson B (eds.). p. 463.

Zadoks, J. C., Chang, T. T. and Konzak, C. F. 1974. A decimal code for the growth stages of cereals. Weed Res. 14:415-421.

Zaffarano, P. L., McDonald, B. A., Zala, Z. and Linde, C. C. 2006. Global Hierarchical Gene Diversity Analysis Suggests the Fertile Crescent Is Not the Center of Origin of the Barley Scald Pathogen Rhynchosporium secalis. Phytopathology 96: 941-950. 